\title{
Genome-Wide Analysis of the Response of Dickeya dadantii 3937 to Plant Antimicrobial Peptides
}

\author{
Isabel Rio-Alvarez, ${ }^{1}$ Jose J. Rodríguez-Herva, ${ }^{1}$ Raquel Cuartas-Lanza, ${ }^{1}$ lan Toth, ${ }^{2}$ Leighton Pritchard, ${ }^{2}$ \\ Pablo Rodríguez-Palenzuela, ${ }^{1}$ and Emilia López-Solanilla ${ }^{1}$ \\ ${ }^{1}$ Centro de Biotecnología y Genómica de Plantas (CBGP), Universidad Politécnica de Madrid-Instituto Nacional de \\ Investigación y Tecnología Agraria y Alimentaria, Pozuelo de Alarcón, Madrid, Spain; ${ }^{2}$ The James Hutton Institute, \\ Invergowrie, Dundee DD25DA, Scotland, U.K.
}

Submitted 22 September 2011. Accepted 18 December 2011.

\begin{abstract}
Antimicrobial peptides constitute an important factor in the defense of plants against pathogens, and bacterial resistance to these peptides have previously been shown to be an important virulence factor in Dickeya dadantii, the causal agent of soft-rot disease of vegetables. In order to understand the bacterial response to antimicrobial peptides, a transcriptional microarray analysis was performed upon treatment with sub-lethal concentration of thionins, a widespread plant peptide. In all, 36 genes were found to be overexpressed, and were classified according to their deduced function as i) transcriptional regulators, ii) transport, and iii) modification of the bacterial membrane. One gene encoding a uricase was found to be repressed. The majority of these genes are known to be under the control of the PhoP/PhoQ system. Five genes representing the different functions induced were selected for further analysis. The results obtained indicate that the presence of antimicrobial peptides induces a complex response which includes peptide-specific elements and general stress-response elements contributing differentially to the virulence in different hosts.
\end{abstract}

Antimicrobial defense peptides are distributed in animals and plants and are among the most ancient host defense factors (García-Olmedo et al. 1998; Hoffman 1995). These peptides share general features such as an overall positive charge, the presence of disulfide bonds in most of them (which stabilize the structure), and a mechanism of action targeting outer membrane structures as well as intracellular antimicrobial activity (Brogden 2005; Caaveiro et al. 1997). Production of plant antimicrobial peptides contributes to so-called plant immunity. Based on amino acid sequence homology, these peptides have been classified as $\alpha$-defensins, thionins, lipid transfer proteins, cyclotides, snakins, and hevein-like (Boman 1995; GarcíaOlmedo et al. 1998; Hammami et al. 2009), and antimicrobial activity in vitro has been reported in all cases. In turn, microbial pathogens have evolved different systems to resist the effect of antimicrobial peptides. These mechanisms can be classified as i) destruction of antimicrobial peptides (by proteolytic digestion), ii) change of antimicrobial peptide target (i.e., the microbial membrane), and iii) removal of antimicrobial

Corresponding author: E. López-Solanilla; Telephone:(+34)913364559; Fax:(+34)917157721; E-mail: emilia.lopez@upm.es

* The $e$-Xtra logo stands for "electronic extra" and indicates three supplementary tables are published online. peptides from their site of action (through efflux pumps or by alteration of the cell surface composition) (Otto 2009). This subject has been extensively studied in gram-positive and gram-negative animal-pathogenic bacteria such as Staphylococcus aureus and Salmonella spp. (Otto 2009).

Dickeya dadantii 3937 (previously Erwinia chrysanthemi) is the causal agent of bacterial soft rot of vegetables, which occurs worldwide and causes a greater total loss of production than any other bacterial disease (Agrios 2005). The pathogenesis of $D$. dadantii 3937 has been intensively studied at the molecular level for several decades, with both extracellular enzymes (including pectinases, cellulases, and proteases, which break down plant cell walls and release nutrients for bacterial growth) and iron uptake being shown to play major roles in pathogenesis (Enard and Expert 2000; Expert 2005; Fagard et al. 2007; Franza et al. 2005; Munzinger et al. 2000; Persmark et al. 1989; Toth et al. 2003). In fact, low iron conditions act as a signal to trigger virulence factors in the bacterium. More recently, other virulence traits have been identified, including resistance mediated by multidrug resistance systems (Maggiorani-Valecillos et al. 2006) and the involvement of motility and chemotaxis during the early stages of infection (Antúnez-Lamas et al. 2009a and b).

The isolation and characterization of mutants in D. dadantii with increased sensitivity to peptides and greatly diminished virulence in plants (López-Solanilla et al. 1998, 2001) identified a key role for this mechanism during infection by $D$. dadantii. One of the determinants of resistance to snakin and thionins in $D$. dadantii is constituted by the "sensitive to antimicrobial peptides" (Sap) system. This system is conserved among plant- and animal-pathogenic bacteria, and a mutation in the system drastically affects the virulence of the bacterium in different hosts (López-Solanilla et al. 1998, 2001; ParraLópez et al. 1993). The Sap system is composed of an ABCtransporter across the inner membrane and a periplasmic protein which could bind and remove the antimicrobial peptides from the membrane, driving them to degradation pathways. Other factors are known to be involved in resistance to plant antimicrobial peptides; for example, in Ralstonia solanacearum, the causal agent of wilt disease in plants, a mutation in $r f a F$ (which encodes a heptosyl transferase involved in lipopolysaccharide [LPS] modification) reduces virulence in tobacco plants and increases the sensitivity to thionins (Titarenko et al. 1997).

PhoP/PhoQ is a two-component regulatory system originally described in Salmonella typhimurium (Groisman et al. 1989; Miller et al. 1989). PhoQ is a histidine kinase sensor present as a dimer in the cytoplasmic membrane, while PhoP is the 
response regulator DNA-binding protein of the system that interacts with target gene promoters (Otto 2009). Upon stimulation, PhoQ trans-autophosphorylates within the dimer and a phosphate is transferred to PhoP. In Salmonella spp., three stimulants of the PhoQ sensor have been described: low concentration of divalent cations (García-Vescovi et al. 1996), low $\mathrm{pH}$ (Alpuche-Aranda et al. 1992), and cationic antimicrobial peptides (Bader et al. 2005). Among the genes regulated by PhoP/PhoQ are those related to $\mathrm{Mg}^{2+}$ transport (Soncini et al. 1996), survival in macrophages (Smith et al. 1998), LPS modifications (Belden and Miller 1994; Guo et al. 1998), and another two-component regulatory system, PmrA/PmrB (Gunn et al. 1998). The analysis of $D$. dadantii 3937 mutants affected in this system has identified its role in processes such as growth and survival at low $\mathrm{pH}$, virulence, regulation of pectolytic enzymes, and sensitivity to plant antimicrobial peptides (Haque and Tsuyumu 2005; Llama-Palacios et al. 2003, 2005). Moreover, Venkatesh and coworkers (2006) have characterized the effect of a $p h o Q$ mutation on the global transcriptional profile of $D$. dadantii 3937. The mutation affects the expression of genes involved in iron metabolism, membrane transporters, stress-related genes, toxins, and transcriptional regulators.

Previous studies in animal-pathogenic bacteria showed that several mechanisms of resistance to antimicrobial peptides in different bacterial species reflect the same molecular strategy, even though the target molecules and genes involved are unrelated. The common theme is the modification of the cell enve- lope, although other responses based on protease production or the function of efflux pumps have been described (Peschel 2002). More detailed information on transcriptional profiling in response to antimicrobial peptides in S. typhimurium, Pseudomonas aeruginosa, or Staphylococcus aureus is available (Bader et al. 2003; Gooderham et al. 2008; Pietiäinen et al. 2009).

The aim of this work was to gain a more complete understanding of the resistance mechanisms used by $D$. dadantii 3937 against antimicrobial peptides, through transcriptional profiling of $D$. dadantii 3937 genes in the presence of thionins (a widely distributed plant antimicrobial peptide). Because the mode of action of these cationic peptides is very similar, it is expected that genes involved in common resistance mechanisms against a broad range of these peptides will be induced and that part of this response contributes to successful plant colonization and disease. Our results show the importance of cell surface modifications, such as the induction of $y b j X$ that has previously been described as one of the contributors to resistance against antimicrobial peptides and, thus, to virulence in Shigella and Salmonella spp. The transcriptional regulators $v f m E$ and $h n s$, which have a known role in virulence, are also induced by the treatment, as well as genes involved in transport mechanisms across the membrane. We selected five of 37 genes for further analysis, because they represent the different types of process induced. Virulence and in vitro susceptibility to antimicrobial peptides of mutant strains in the selected genes revealed different roles in both resistance and virulence.

Table 1. Microarray hybridization results ${ }^{\mathrm{a}}$

\begin{tabular}{|c|c|c|c|c|}
\hline ID & Fold change & Gene name & Description & $\begin{array}{l}\text { Fold change in } \\
\text { phoP mutant }\end{array}$ \\
\hline 19503 & 17.74 & $y b j X$ & Virk & 1.06 \\
\hline 16056 & 7.44 & $\ldots$ & Hypothetical protein & 1.06 \\
\hline 16248 & 5.79 & $\operatorname{arn} B$ & UDP-4-amino-4-deoxy-L-arabinose $\alpha$-ketoglutarate aminotransferase & 1.30 \\
\hline 16247 & 5.01 & $\operatorname{arnC}$ & Undecaprenyl-phosphate 4-amino-4-deoxy-L-arabinose transferase & 1.78 \\
\hline 20334 & 4.34 & yeiU & Undecaprenyl pyrophosphate phosphatase & 1.05 \\
\hline 16850 & 4.26 & $\ldots$ & Nucleoside-diphosphate-sugar epimerases & -1.32 \\
\hline 19491 & 3.91 & $\ldots$ & Spore maturation protein & 1.01 \\
\hline 16245 & 3.69 & $y f b G$ & Bifunctional UDP-L-Ara4N formyltransferase/UDP-glcA C-4'-decarboxylase & 1.34 \\
\hline 16073 & 3.63 & $v f m E$ & Transcriptional regulator. AraC family & 1.33 \\
\hline 17764 & 3.60 & phoP & DNA-binding response regulator in two-component regulatory system & 1.03 \\
\hline 19051 & 3.35 & yeeZ & Predicted epimerase. With NAD(P)-binding Rossmann-fold domain & 1.05 \\
\hline 14884 & 3.16 & cysH & 3'-Phosphoadenosine-5'-phosphosulfate sulfotransferase & 1.22 \\
\hline 19405 & 3.05 & $\ldots$ & Glyoxalase/Bleomycin resistance protein/dioxygenase domain & $2.05^{*}$ \\
\hline 16066 & 2.80 & $\ldots$ & Hypothetical protein & 1.25 \\
\hline 17765 & 2.57 & phoQ & Sensory histidine kinase in two-component regulatory system & 1.17 \\
\hline 18174 & 2.44 & $\ldots$ & Periplasmic binding protein & -1.05 \\
\hline 16244 & 2.43 & $y f b H$ & Undecaprenyl phosphate- $\alpha$-L-Ara4FN deformylase & 1.14 \\
\hline 14594 & 2.42 & $\operatorname{sly} B$ & Outer membrane lipoprotein & 1.62 \\
\hline 16071 & 2.39 & untA & $\mathrm{ABC}$ transporter. ATP-binding protein & 1.80 \\
\hline 20481 & 2.34 & $\ldots$ & Virk protein & $2.11 *$ \\
\hline 16070 & 2.31 & untM & Antimicrobial peptide $\mathrm{ABC}$ transporter. Permease component & 1.16 \\
\hline 19408 & 2.31 & $\ldots$ & Hypothetical protein & 1.09 \\
\hline 19410 & 2.28 & $\ldots$ & Hypothetical protein & 1.22 \\
\hline 18175 & 2.27 & $\ldots$ & ABC-type Fe $3+$-siderophore transport system. Permease component & 1.10 \\
\hline 19403 & 2.25 & $\ldots$ & Acyl-coA dehydrogenase, short-chain specific & 1.79 \\
\hline 16078 & 2.23 & $\ldots$ & Hypothetical protein & 1.29 \\
\hline 15686 & 2.23 & $y r b D$ & Predicted ABC-type organic solvent transporter & 1.23 \\
\hline 17830 & 2.17 & yjeI & Conserved protein & $2.30 *$ \\
\hline 17560 & 2.16 & yajI & Putative outer membrane lipoprotein & -1.05 \\
\hline 19411 & 2.15 & virA & Diaminopimelate decarboxylase & 1.58 \\
\hline 16240 & 2.06 & pmrM & Polymyxin resistance protein & 1.67 \\
\hline 19409 & 2.05 & $\ldots$ & Long-chain-fatty-acid-coA ligase & 1.87 \\
\hline 14801 & 2.05 & viaA & Von Willebrand Factor Type A (VWA) domain-containing protein & 1.06 \\
\hline 20646 & 2.00 & hns & Global DNA-binding transcriptional dual regulator H-NS & 1.63 \\
\hline 20236 & 2.00 & $y b h L$ & Putative membrane protein & 1.03 \\
\hline 16242 & 1.96 & $\operatorname{arnT}$ & 4-Amino-4-deoxy-L-arabinose transferase & -1.22 \\
\hline 18563 & -2.19 & $\ldots$ & Uricase & 1.21 \\
\hline
\end{tabular}

${ }^{a}$ Dickeya dadantii 3937 treated with thionins. Nomenclature from the ASAP database. Genes selected for this study are in bold. Results are the mean of normalized expression values derived from three biological replicates; * indicates genes that did not change their expression levels in the phoP mutant in the presence of thionins. 
A similar analysis in the phoP mutant enables us to determine the involvement of this regulator in the global response to antimicrobial peptides.

\section{RESULTS}

Transcriptomic analysis of the response of $D$. dadantii 3937 to thionins.

Previous reports have shown the multifactorial nature of the response to antimicrobial peptides in D. dadantii (LlamaPalacios et al. 2003, 2005; López-Solanilla et al. 1998, 2001). To obtain an overview of this response at the transcriptional level, we carried out microarray hybridization experiments. It was previously described that the response to antimicrobial peptides in different plant- and animal-pathogenic bacteria is under the control of the PhoP/PhoQ two-component regulatory system (Groisman 2001). To ascertain whether there was a similar regulatory process in $D$. dadantii 3937 , we first compared gene expression patterns of a phoP mutant strain with that of the wild-type (WT) strain.

Total RNA isolated from $D$. dadantii 3937 WT or phoP mutant strains after treatment in the presence or absence of 30 $\mu \mathrm{M}$ thionins for $40 \mathrm{~min}$ was used for microarray analysis, as described below. In the WT strain, 37 genes showed a differential expression in the presence of thionins. Most of these genes exhibited an increased level in transcript abundance compared with the control, with a fold change higher than 1.95. Only one gene, ABF-0018563, encoding a uricase was downregulated after the treatment with thionins (fold change, -2.19) (Table 1).

Most of the upregulated genes are known to be involved in resistance to antimicrobials at the level of membrane modifications or were related to transport functions through the bacterial membrane. Moreover, three regulatory systems were upregulated: PhoP/PhoQ, VfmE, and Hns. All have been previously described as virulence regulators in D. dadantii 3937 (Costechareyre et al. 2010; Llama-Palacios et al. 2003, 2005; Nasser and Reverchon 2002) and, in the case of the PhoP/PhoQ global regulator, its activity has been specifically related to resistance against antimicrobial peptides in different pathogenic bacteria (Groisman 2001).

From the set of upregulated genes, five genes were chosen for further analysis based on both the high fold change and their predicted function. ABF-0019503 and ABF-0016056 were selected for their high fold change, 17.74 and 7.44, respectively. ABF-0019503 ( $y b j X)$ shows similarity (57\% amino acid identity) to the Shigella flexnerii VirK protein, which is involved in resistance to antimicrobial peptides in this pathogen (Wing et al. 2005). ABF-0016056 encodes a hypothetical protein. Three more genes whose expression was upregulated between twoand threefold were also selected. ABF-0019051 (yeeZ) is predicted to encode a putative epimerase; other enzymes related to LPS sugar modifications are involved in resistance to antimicrobial peptides (Gunn et al. 1998; Guo et al. 1998; Titarenko et al. 1997); ABF-0016070 encodes the UntM protein, an ABCtransporter permease involved in drug resistance; and $\mathrm{ABF}$ 0016242 encodes the ArnT protein, an arabinose transferase implicated in resistance against the antimicrobial peptide polymyxin in Salmonella enterica serovar typhimurium and Escherichia coli (Trent et al. 2001).

In the case of the phoP mutant, microarray results showed that 33 of the 36 genes that were upregulated in the WT strain in the presence of thionins did not change their expression levels in the mutant treated with thionins (Table 1), which suggests direct or indirect regulation of these genes by the PhoP/PhoQ system. To confirm the microarray results, quantitative real-time polymerase chain reaction (qRT-PCR) experiments were performed on the selected genes (Fig. 1) and statistical analysis showed that, in all cases, the differential expression between the treated and the control samples was significant $(P<0.05$ according to a one-tailed $t$ test).

\section{PhoP regulator binds to the promoter region of $y b j X$.}

Because microarray data is not able to distinguish between direct and indirect regulation, we carried out electrophoretic mobility shift assays (EMSA) with the five selected genes to ascertain whether they were under the direct control of the PhoP regulator. The 6 His-PhoP recombinant protein was purified (Fig. 2A and B) and EMSA assays were conducted to test the binding of $6 \mathrm{His}-\mathrm{PhoP}$ to the region upstream of the predicted translation start site for each gene. To ensure the specificity of EMSA, one additional gene (ABF-0020481) was included as a negative control because it is known to be directly regulated by the PecS regulator (Hommais et al. 2008). The results of the EMSA tests (Fig. 2C) show binding for the $y b j X$ gene only, supporting the direct control of this gene by the PhoP regulator and the indirect control of the remaining four genes in the assay conditions used.

\section{Virulence involvement of genes induced by thionins.}

Mutants affected in genes ABF-0016056, untM, and $y b j X$ were isolated from a $D$. dadantii 3937 mutation grid available in our lab (below), while mutants for genes yeeZ and arnT were produced by Tn7 in vitro mutagenesis followed by specific marker exchange. The abilities of the mutant strains to cause disease was assayed in chicory leaves, potato tubers, and African violet (Saintpaulia ionantha) plants, which are three
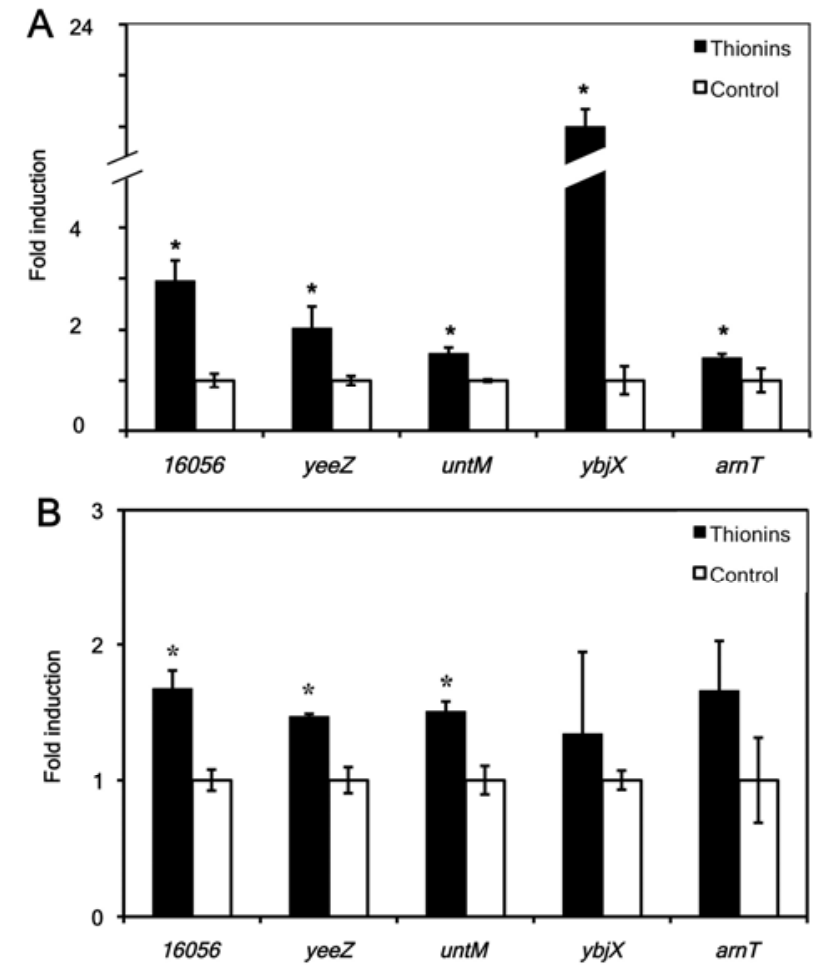

Fig. 1. Quantitative real-time polymerase chain reaction (qRT-PCR) of the genes under study in Dickeya dadantii 3937 and phoP mutant (BT118) strains in the presence of thionins. Quantification of transcripts by qRT-PCR in $\mathbf{A}$, D. dadantii 3937 and $\mathbf{B}$, phoP mutant induced in response to thionins. Fold change in the presence of thionins $(30 \mu \mathrm{M})$ or distilled water control. Statistical analysis to describe the relative relationship between the test and control samples was carried out as previously described by Pfaffl (2001) and Rotenberg and associates (2006) using the rpoS gene as an internal control. Results are means from three independent experiments. Differences in relative expression ratio with respect to the internal controls were statistically significant $(P<0.05)$ in all cases according to a one-tailed $t$ test. 
hosts of $D$. dadantii 3937 . In the standard chicory assay, mutants affected in untM, $y b j X$ (VirK homolog), and arnT showed decreased virulence compared with the WT strain (Fig. 3A). In potato tubers, in addition to these three strains, the $\mathrm{ABF}$ 0016056 mutant was also affected in its virulence (Fig. 3B). However, in African violet, the mutants most affected in virulence were in the putative epimerase YeeZ, $y b j X$ (VirK homo$\log$ ), and $\operatorname{arnT}$ (Fig. 3C). The mutant strains were complemented and their virulence was analyzed, showing a partial complementation in all the hosts tested (data not shown).

\section{Susceptibility of mutant strains to antimicrobial peptides.}

To determine whether the selected genes were directly involved in resistance against thionins, in vitro susceptibility assays were performed in the presence of this antimicrobial peptide. In these experiments, the BT105 strain, which carries a mutation in the sap operon, was included as a positive control for the activity of the antimicrobial peptide. The Sap system was previously shown to contribute to resistance against plant antimicrobial peptides in D. dadantii 3937 (LópezSolanilla et al. 1998). Experiments in Figure 4 show that, under treatment of $100 \mu \mathrm{M}$ thionins, the survival of the untM and $y b j X$ mutant strains was approximately $70 \%$ of that of the WT strain, indicating the involvement of these genes in resistance to this peptide. When the mutations were complemented, the survival percentages were similar to those of the WT strain (data not shown). The $y b j X$ strain appears to be the most sensitive to thionins and its virulence was compromised in all of the tested hosts. To test whether this gene was also involved in resistance against other plant antimicrobial peptides, we carried out similar in vitro susceptibility assays in the presence of snakin-2, one of the most abundant antimicrobial peptides in potato tubers. Cell survival of the $y b j X$ mutant strain was significantly lower than that of the WT at the concentrations assayed (Fig. 5). The virulence of the arnT mutant is also compromised in all the tested hosts. In spite of being as resistant as the WT strain to thionins, its survival is compromised in the presence of snakin-2 (Fig. 5).

\section{Increased virulence}

of $D$. dadantii 3937 bacterial cells pretreated with thionins.

In addition to altering the expression of genes potentially involved in virulence and resistance against thionins, we investigated whether thionins also induced other mechanisms that increase bacterial survival in the apoplast and, thus, promote disease symptoms in the plant. To test this hypothesis, virulence of the WT strain pretreated with thionins was analyzed and compared in potato tubers with that of nontreated control cells. The macerated area was significantly larger following pretreatment with thionins (Fig. 6), suggesting that this peptide may act as a signal that triggers the onset of virulence.

\section{DISCUSSION}

Resistance to antimicrobial peptides is a common feature during bacterial infection of plants and animals and it has become an object of many groups to investigate the potential of these molecules as tools to control bacterial infections (Otto 2009; Peschel 2002). In animal-pathogenic bacteria, this study area has been covered mainly in Salmonella and Staphylococcus spp., which are gram-negative and gram-positive, respectively (Otto 2009; Peschel 2002).

Here, we examined gene expression in D. dadantii 3937 in the presence of the antimicrobial peptide thionins. The changes

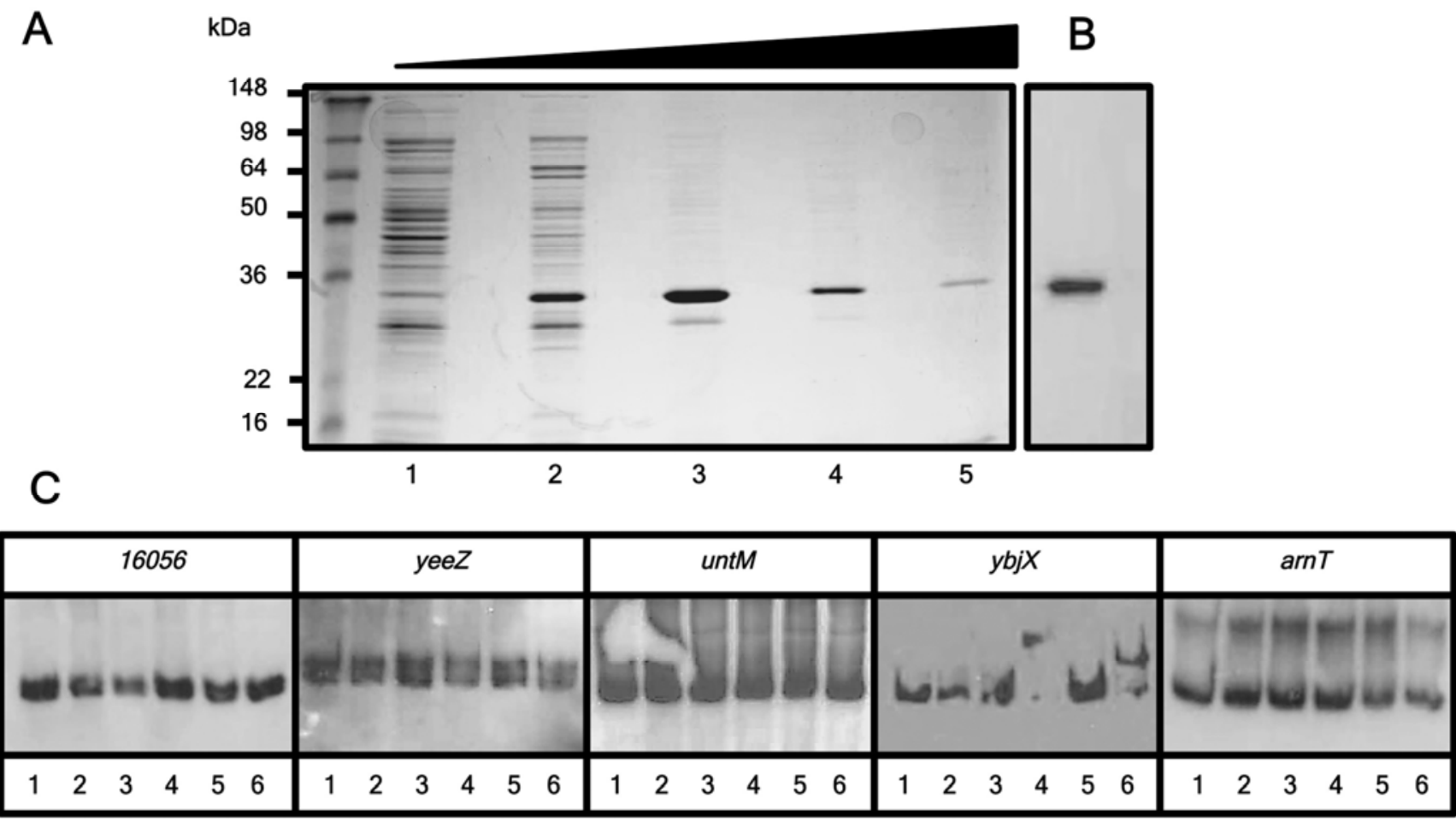

Fig. 2. Binding of PhoP to promoter regions of genes under study. A, The 6His-PhoP protein was purified using increasing amount of imidazole (lanes 1 to 5 : 20, 50, 100, 150, and $250 \mathrm{mM}$, respectively) and its purity was checked by sodium dodecyl sulfate polyacrylamide gel electrophoresis. B, An immunoblot was carried out to check the presence of 6 His-PhoP protein. $\mathbf{C}, 16056$, yeeZ, unt $M, y b j X$, and arnT promoter regions were amplified by polymerase chain reaction and labeled with biotin. For each experiment, $100 \mathrm{fmol}$ of labeled DNA probe (lane 1) was incubated with increasing amounts of 6 His-PhoP transcriptional regulator $(10,15$, and 30 pmol) (lanes 2, 3, and 4, respectively). For the cold probe control, 100 fmol of labeled DNA probe and 30 pmol of 6 HisPhoP were mixed with 20x unlabeled DNA probe for competition assay (lane 5). For the negative control, 100 fmol of labeled DNA probe and 30 pmol of 6His-PhoP were mixed with 1× unlabeled DNA probe (ABF-0020418) (lane 6). 
in gene expression showed a general pattern of induction of genes related to lipopolysaccharide modifications, transcriptional regulators, and transport systems.

In all, seven of 37 genes showing differential expression (ABF-0016240 to ABF-0016248 and ABF-0020334) encoded
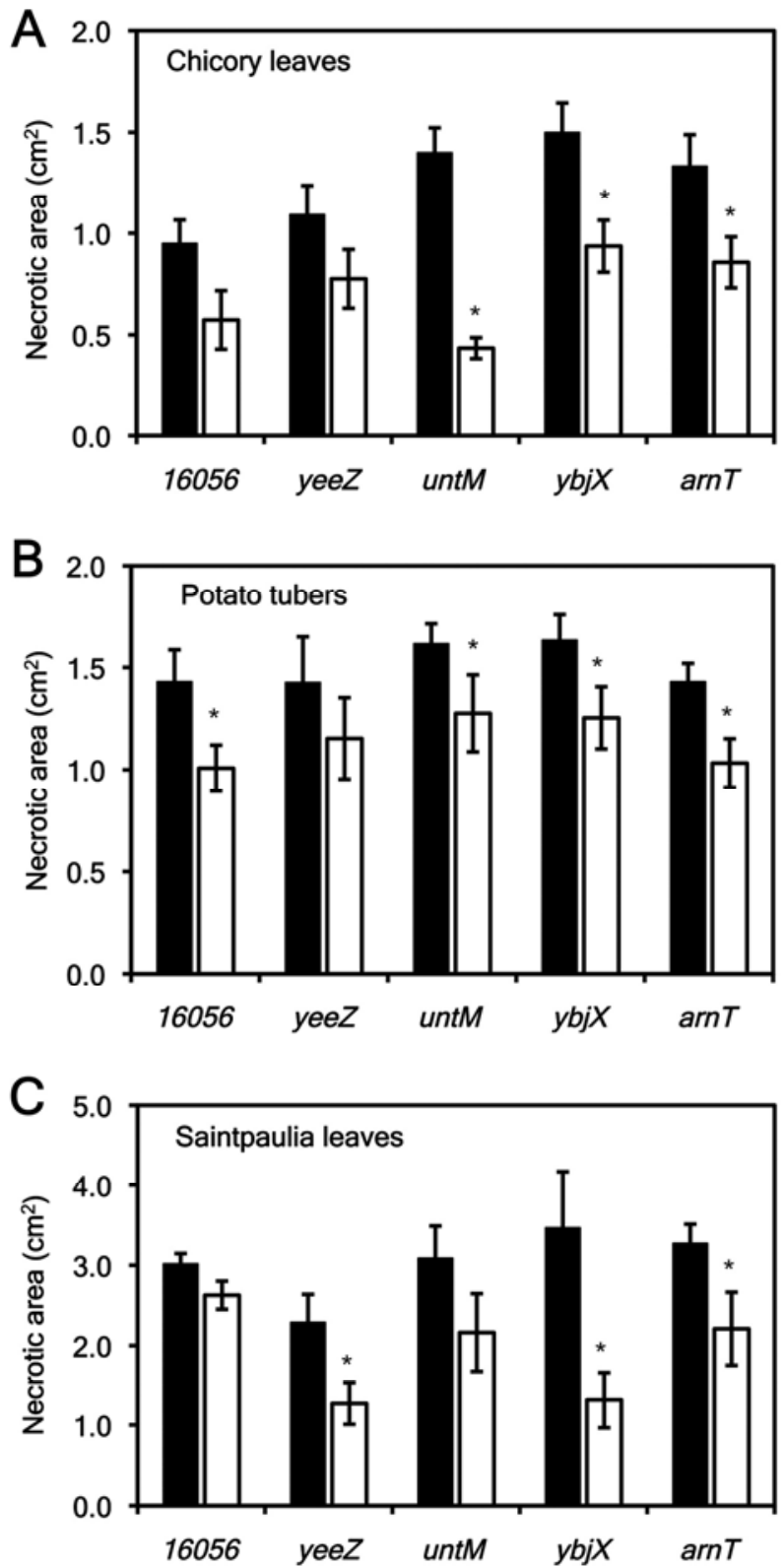

Fig. 3. Virulence assays in three different hosts of Dickeya dadantii 3937. A, Virulence in a paired-inoculum test in chicory leaves. Leaves were pair inoculated for each comparison, with $10 \mu \mathrm{l}$ of inocula of a bacterial suspension containing $5 \times 10^{4}$ cells of the wild-type (black bars) and the mutant (white bars), respectively. Values are means of the necrotic area produced in several leaves after $24 \mathrm{~h}$ of incubation at $28^{\circ} \mathrm{C}$ with high humidity. B, Virulence in a paired-inoculum test in potato tubers. Tubers were pair inoculated for each comparison, with $20 \mu \mathrm{l}$ of inocula of a bacterial suspension containing $5 \times 10^{5}$ cells of the wild-type (black bars) and the mutant (white bars), respectively. Values are means of the necrotic area produced in several leaves after $48 \mathrm{~h}$ of incubation at $28^{\circ} \mathrm{C}$ with high humidity. C, Virulence in a paired-inoculum test in Saintpaulia ionantha leaves. Leaves were pair inoculated for each comparison, with $100 \mu \mathrm{l}$ of inocula of a bacterial suspension containing $5 \times 10^{6}$ cells of the wild-type (black bars) and the mutant (white bars), respectively. Values are means of the necrotic area produced in several leaves after $48 \mathrm{~h}$ of incubation at $28^{\circ} \mathrm{C}$ with high humidity. Error bars represent the standard error; * indicates significant at the $5 \%$ level in a paired test. proteins with homologs in Salmonella spp., which have been implicated in the 4-aminoarabinose (Ara4N) addition to lipid A and polymyxin resistance (Gunn et al. 1998). Ara4N-containing lipid A results in a less negatively charged bacterial surface, which reduces antimicrobial peptide binding and promotes resistance to the cationic peptides polymyxin $\mathrm{B}$ and to azurocidin. Following production of a mutant affected in arnT (ABF-0016242), the role of this gene was investigated for its effect on resistance to plant antimicrobial peptides and virulence in different hosts. Although resistance to thionins was not significantly modified, this mutant showed a high sensitivity to snakin-2, and its virulence on all hosts tested was reduced (Figs. 3 and 5). A possible explanation for this apparent paradox lies in the fact that $D$. dadantii 3937 has to survive in the environment of different plant hosts which contains a wide variety of antimicrobial peptides, and the contribution of this particular system to thionins resistance may be low. In contrast,

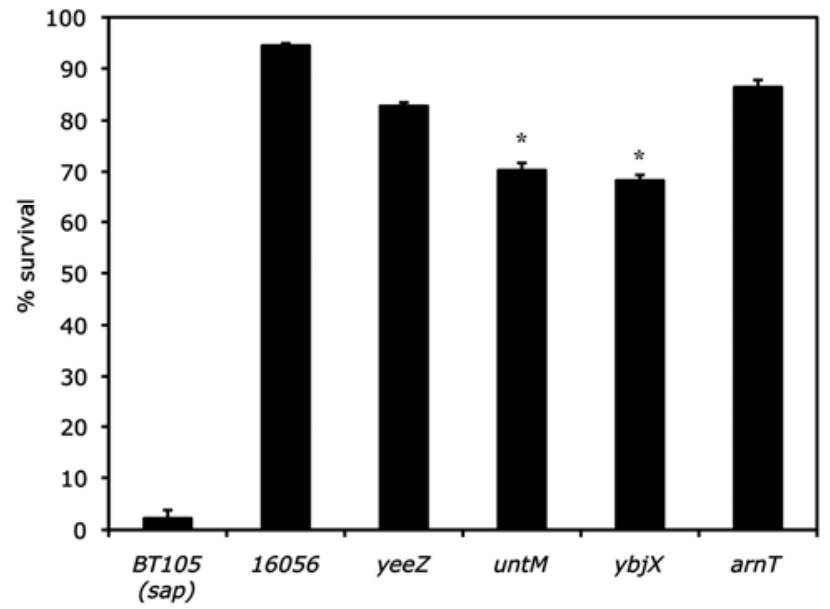

Fig. 4. Susceptibility of Dickeya dadantii 3937 and mutant strains to thionins. Bacteria and thionins at a concentration of $100 \mu \mathrm{M}$ were incubated at $28^{\circ} \mathrm{C}$ for $6 \mathrm{~h}$, diluted, and plated in King's B agar plates. Bacterial survival was measured by counting CFU. Results are expressed as percentages of survival with respect to that of the wild-type strain. Results are for a typical experiment from three independent trials. Error bars represent the standard error; * indicates significant at the $5 \%$ level in a paired test.

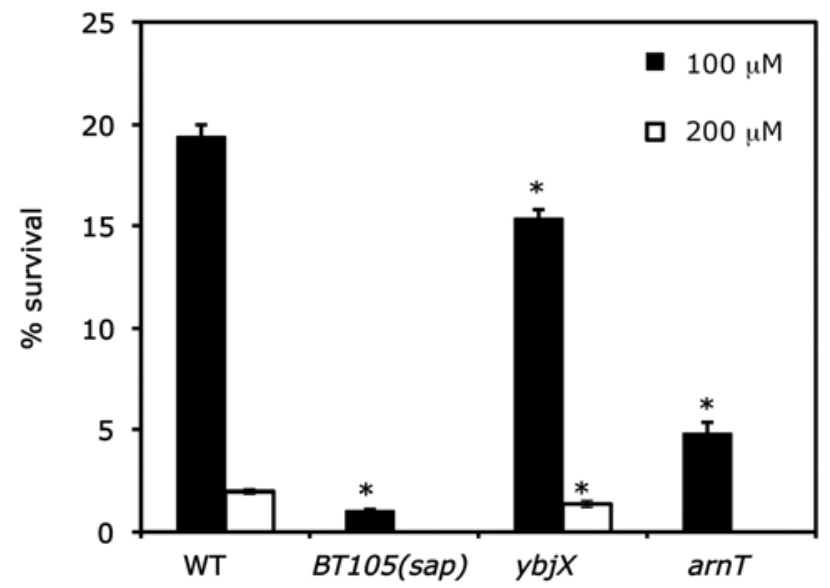

Fig. 5. Susceptibility assay of $y b j X$ and $\operatorname{arnT}$ to snakin-2. Bacteria and snakin-2 at $100 \mu \mathrm{M}$ (black bars) or $200 \mu \mathrm{M}$ (white bars) were incubated at $28^{\circ} \mathrm{C}$ for $6 \mathrm{~h}$, diluted, and plated in nutrient broth agar plates. Bacterial survival was measured by counting CFU. Data represent the percentage of survival of treated samples with respect to that of the corresponding nontreated samples. Results are for a typical experiment from three independent trials. Error bars represent the standard error; * indicates that differences in survival percentage were statistically significant $(P<0.05)$ in all cases according to a one-tailed $t$ test. 
this system appears to be essential for resistance to snakin-2, another peptide abundant in potato tuber (Berrocal-Lobo et al. 2002). yeiU (ABF-0020334), also induced upon treatment, has been shown to mediate the modification of lipid A with an additional phosphate group at the 1-position, forming a 1-diphosphate species. This gene is called lpxT in E. coli (Touze et al. 2008). The inhibition of $\operatorname{lp} x T$ is required for phosphoethanolamine decoration of lipid A, which is critical for $E$. coli to resist the bactericidal activity of polymyxin (Herrera et al. 2010).

In line with this general response to modification of the bacterial membrane is the induction of $y b j X$ (ABF-0019503). The induction rate of this gene is significantly higher than all other induced genes, and its mutation was also shown to affect virulence of $D$. dadantii 3937 in several hosts, including potato. This mutation has a significant effect on the resistance of this strain to one of the more abundant antimicrobial peptides in potato tissue, Snakin-2 (Berrocal-Lobo et al. 2002). This mutation also affects in vitro resistance to thionins. Taken together, these results suggest a pivotal role of this protein on the basic response to cationic antimicrobial peptides in this bacterium. There are several reports describing the implication of homologous proteins to $y b j X$ in intercellular spread and virulence in Shigella flexneri, Listeria innocua, E. coli, and Campylobacter jejuni (Kocks et al. 1995; Nakata et al. 1992; Novik et al. 2009; Shere et al. 1997). Also, in Salmonella enterica serovar typhymurium, this protein is implicated in the systemic infection process and in resistance to cationic peptides (Brodsky et al. 2005; Detweiler et al. 2003). Although the precise function of $y b j X$ homologs (called virK in other bacteria but different from the annotated virK in D. dadantii 3937) has not been determined, some indirect evidence suggests that VirK is functionally linked to LPS modification and may modulate the activities of other bacterial proteins by locating them to an appropriate site or maintaining the correct interactions with lipid A of certain proteins implicated in virulence (Novik et al. 2009; Wing et al. 2005). It is believed that VirK exerts this effect by regulating the stability or activity of IcsP, a protease required for the posttranslational modification of IcsA, which is an actin assembly protein of Shigella spp. involved in bacterial spread (Wing et al. 2005). There are no conserved homologs to IcsP and IcsA in D. dadantii 3937 but this finding will merit future investigations into new factors involved in D. dadantii 3937 virulence.

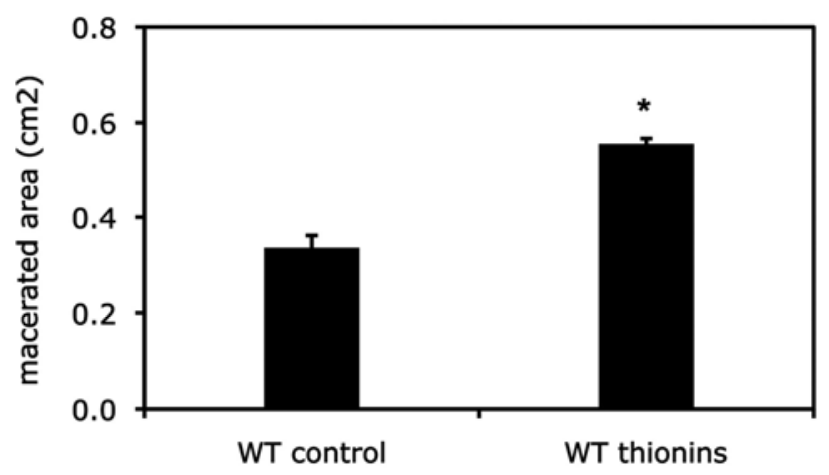

Fig. 6. Virulence induction in potato tubers after thionins exposure. Dickeya dadantii 3937 wild-type strain was grown to an optical density at $600 \mathrm{~nm}=$ 0.2 . Cells were pretreated with thionins at $30 \mu \mathrm{M}$ or distilled water and the cultures were then grown for an additional $60 \mathrm{~min}$. Cells were washed and a classic potato virulence assay was carried out. Results are for a typical experiment from three independent trials; * indicates that differences in macerated area were statistically significant $(P<0.05)$ in all cases according to a one-tailed $t$ test.
Other genes induced by thionins, including ABF-0016850 and ABF-0019051 (yeeZ), which encode putative sugar epimerases, may be involved in sugar modifications of the membrane LPS (although there is currently no experimental evidence for this) and could be related to metabolic adaptation instead. A mutant in yeeZ (ABF-0019051) showed diminished virulence in potato tubers, one of the tissues more easily infected by this bacterium, but was not significantly affected in the other hosts tissues tested. The relevance of this specificity could again relate to membrane modifications required for resistance to certain antimicrobials in different hosts or in an adaptation of metabolism in different hosts. Other genes which are induced by our treatment could be related to a metabolic function, including ABF-0014884, which encodes a sulfotransferase; and ABF-0019409 and ABF-0019411, which encode an Acyl-CoA dehydrogenase/oxidase and a diaminopimelate decarboxylase, respectively.

The induction of transport systems by antimicrobial peptides is another common feature of this response among bacteria. Our analysis showed the induction of systems such as UntAUntM (ABF-0016071 and ABF-0016070), annotated as an antimicrobial peptide transporter. The untM gene was selected for further analysis and the mutant strain was shown to be affected in African violet and chicory, suggesting specificity for the transport of abundant peptides in these tissues. The in vitro susceptibility assay showed that this strain is also affected in its resistance to thionins specifically, which is an abundant peptide in green tissues. The unt $M$ gene was previously described as being under the control of HrpY (Yap et al. 2008). This protein is involved in the regulation of the type III secretion system (T3SS) expression in D. dadantii 3937 in response to environmental signals ( $\mathrm{Li}$ et al. 2009; Yang et al. 2004, 2008), which suggests a link to the activation of this system. In fact, other genes induced by our treatment, including ABF-0019405, have been described as under the control of HrpL, the transcriptional regulator of the T3SS (Yang et al. 2010).

Other genes related to transport functions were also induced in our assay and include the $y r b D$ gene (ABF-0015686) and genes $\mathrm{ABF}-0018174$ to -18175 , which encode a periplasmic binding protein and an $\mathrm{ABC}$-type $\mathrm{Fe}^{+}$siderophore transport system, respectively. Iron homeostasis has been previously related to virulence of this bacterium, and Venkatesh and coworkers (2006) found that the expression of different genes related to iron metabolism is altered in a $p h o Q$ mutant.

The response to thionins also includes the induction of the central stress regulators PhoP/PhoQ, Hns, and VfmE previously associated with virulence in D. dadantii 3937 (Costechareyre et al. 2010; Nasser and Reverchon 2002; Venkatesh et al. 2006). The two-component regulatory system PhoP/PhoQ controls the response to antimicrobial peptides and other virulence processes in many bacteria, including $D$. dadantii 3937 , and these genes were expected to be induced by treatment with thionins. The same treatment on the phoP mutant allowed us to determine that almost all genes induced by the peptides are directly or indirectly under the control of PhoP, indicating a central role for this system in the response. The EMSA experiments carried out with selected genes showed that only $y b j X$ is under the direct control of PhoP. It is noteworthy that $y b j X$ showed the highest level of induction and the mutant is the most affected regarding virulence in different hosts and resistance to antimicrobial peptides.

One well-known aspect of regulation during the response to antimicrobial peptides by PhoP-PhoQ is the activation of the PmrA-PmrB regulon (resistance to polymyxim through lipid A modification) through PmrD (Gunn et al. 2008). In our analysis, the homologs of genes under the control of PmrA-PmrB were induced (ABF-0016240 to -0016248 and ABF-0020334) but we 
have not found a conserved homolog to PmrD in D. dadantii 3937, suggesting that, in this bacterium, the PhoP control of this regulon could be mediated by another protein as is the case in E. coli (Winfield and Groissman 2004).

The presence of different types of antimicrobial peptides in different hosts suggests that the concerted induction of other virulence regulators such as Hns and VfmE, together with PhoP, would benefit bacterial survival. Interestingly, the treatment with sub-lethal concentrations of thionins increased the virulence of $D$. dadantii 3937, suggesting that gene expression changes induced by the peptides confer a general adaptation to the plant environment and induce the virulence program of the bacterium.

Another gene induced by the treatment with thionins is $s l y B$. Expression of $s l y B$ is controlled by PhoP in E. coli and Yersinia and Salmonella spp. (Eguchi et al. 2004; Lejona et al. 2003; Perez et al. 2009), and encodes a product that negatively regulates PhoP activity and is critical for the proper functioning of the PhoP/PhoQ system. Our results correlate with the expected PhoP-mediated induction in D. dadantii 3937.

In line with the onset of virulence mechanisms in response to the presence of antimicrobial peptides is the repression of a uricase (ABF-0018563), which was found in our analysis. Perera and Grove (2010) showed that urate is an efficient natural ligand for PecS (a virulence regulator in phytopathogenic bacteria), attenuating the binding of PecS to its operator DNA in vitro. Furthermore, exogenous urate causes upregulation of both pecS and pecM genes, suggesting that it can function as an efficient effector in vivo. The repression of this enzyme involved in urate degradation and subsequent increase of urate levels suggest that this molecule would induce, by binding $\mathrm{PecS}$, the expression of virulence genes under the control of this repressor. This interesting finding will merit future investigation to better understand the regulatory network taking place during the switch to virulence in $D$. dadantii 3937.

The Sap system previously described as being involved in resistance to thionins, with a relevant contribution on virulence (López-Solanilla et al. 1998, 2001), is not inducible by this treatment. This result could indicate that the system is induced by other signals present in the plant environment or, alterna- tively, being constitutively expressed under the conditions tested. A similar assay in Salmonella typhimurium, where this system is functionally conserved, also showed that it is not induced by antimicrobial peptide treatment (Bader et al. 2003).

In summary, this work indicates that the presence of the broad distributed antimicrobial peptides, thionins, induces changes in gene expression directed mainly toward modification of outer membrane characteristics and connections to virulence regulons.

The analysis of virulence and in vitro resistance of a given number of selected genes, and the induction of virulence by the peptide treatment, led us to suggest that this response may have both peptide-specific elements that contribute differentially to virulence in different hosts and general stress-response elements contributing to the adaptation process to the plant environment.

\section{MATERIALS AND METHODS}

\section{Bacterial strains, plasmids, and growth conditions.}

The bacterial strains and plasmids used in this study are listed in Table 2. Strains of E. coli were grown at $37^{\circ} \mathrm{C}$ in Luria-Bertani medium (Sambrook et al. 1989). Strains of $D$. dadantii 3937 were cultivated at $28^{\circ} \mathrm{C}$ in nutrient broth (N1) (yeast extract, $1 \mathrm{~g} /$ liter; beef extract, $2 \mathrm{~g} / \mathrm{liter}$; $\mathrm{NaCl}, 5 \mathrm{~g} / \mathrm{liter}$; and bactopeptone, $5 \mathrm{~g} / \mathrm{liter}$ ) or King's B medium (King et al. 1954). When required, antibiotics were used at the following final concentrations: ampicillin (Ap), $100 \mu \mathrm{g} / \mathrm{ml}$; kanamycin $(\mathrm{Km}), 20 \mu \mathrm{g} / \mathrm{ml}$; neomycin (Neo), $40 \mu \mathrm{g} / \mathrm{ml}$; and spectinomy$\operatorname{cin}(\mathrm{Sp}), 50 \mu \mathrm{g} / \mathrm{ml}$.

\section{Mutant construction.}

To analyze the functions of the genes of interest in $D$. dadantii 3937, an arrayed set of insertional mutants (mutation grid) was constructed as follows. In vivo transposon mutagenesis of D. dadantii 3937 was performed by conjugation using E. coli S17-1 $\lambda$ pir (pCAM140) as donor strain. Selection of exconjugants was done on polygalacturonic acid (PGA) sodium dodecyl sulfate (SDS) minimal medium (PGA, 2 g/liter; SDS, $0.01 \%$ [wt/vol]; and agar, $15 \mathrm{~g} / \mathrm{liter})$ supplemented with $\mathrm{Sp}$ and Neo. The exconjugants $(n=7,296)$ were tested for sensitivity to Ap

Table 2. Bacterial strains and plasmids

\begin{tabular}{|c|c|c|}
\hline Strain or plasmid & Relevant characteristics $^{\mathbf{a}}$ & Source or reference $^{b}$ \\
\hline \multicolumn{3}{|l|}{ Strains } \\
\hline \multicolumn{3}{|l|}{ Escherichia coli } \\
\hline DH5 $\alpha$ & supE44 $\Delta l a c \mathrm{U} 169$ ( (80 lacZAM15) hsdR17 recA1 endA1 gyrA96 thi-1 relA1 & Hanahan 1983 \\
\hline S17-1 $\lambda$ pir & $\lambda$ pir lysogen of S17-1 & Victor de Lorenzo, CNB \\
\hline BL21 (DE3) & $\mathrm{F}^{-}, o m p T, h s d S_{B} d c m$, gal, tonA & Invitrogen \\
\hline \multicolumn{3}{|l|}{ Dickeya dadantii } \\
\hline 3937 & Wild-type strain & Kotoujansky et al. 1985 \\
\hline BT118 & $\Delta p h o P:: \operatorname{Tn} 7 \mathrm{Km}^{\mathrm{r}}$ derivative of $\mathrm{EC} 16$ & Llama-Palacios et al. 2003 \\
\hline BT105 & $\Delta s a p A:: \Omega \mathrm{Sp}^{\mathrm{r}} / \mathrm{Sm}^{\mathrm{r}}$ derivative of $\mathrm{AC} 4150$ & López-Solanilla et al. 1998 \\
\hline 16056 & $16056:: \operatorname{Tn} 5 \mathrm{Sp}^{\mathrm{r}}$ derivative of 3937 & This work \\
\hline yeeZ & yeeZ::Tn7 $\mathrm{Km}^{\mathrm{r}}$ derivative of 3937 & This work \\
\hline unt $M$ & unt $M:: \operatorname{Tn} 5 \mathrm{Sp}^{\mathrm{r}}$ derivative of 3937 & This work \\
\hline$y b j X$ & $y b j X:: \operatorname{Tn} 5 \mathrm{Sp}^{\mathrm{r}}$ derivative of 3937 & This work \\
\hline $\operatorname{arnT}$ & $\operatorname{arnT}:: \operatorname{Tn} 7 \mathrm{Km}^{\mathrm{r}}$ derivative of 3937 & This work \\
\hline \multicolumn{3}{|l|}{ Plasmids } \\
\hline pGEM T-easy & Polymerase chain reaction cloning vector, $\mathrm{Ap}^{\mathrm{r}}$ & Promega \\
\hline pGEM T-easy-16056 & 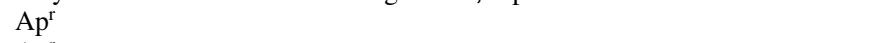 & This work \\
\hline pGEM T-easy-yeeZ & $\mathrm{Ap}^{\mathrm{r}}$ & This work \\
\hline pGEM T-easy-untM & $\mathrm{Ap}^{\mathrm{r}}$ & This work \\
\hline pGEM T-easy-ybjX & $A p^{r}$ & This work \\
\hline pGEM T-easy-arnT & $A p^{r}$ & This work \\
\hline pCAM- 140 & $\mathrm{Sm}^{\mathrm{r}} / \mathrm{Sp}^{\mathrm{r}}, \mathrm{Ap}^{\mathrm{r}} ; \mathrm{mTn} 5 \mathrm{SS} g u s A 40$ (promoterless gusA for transcriptional fusions) & Wilson et al. 1995 \\
\hline pDEST17 & His $_{6}$-tagged protein expression vector, $\mathrm{Ap}^{\mathrm{r}}$ & Invitrogen \\
\hline pDEST17-6HisPhoP & His $_{6}$-tagged PhoP expression vector, $\mathrm{Ap}^{\mathrm{r}}$ & This work \\
\hline
\end{tabular}

${ }^{\mathrm{a}} \mathrm{Km}^{\mathrm{r}}, \mathrm{Sp}^{\mathrm{r}}, \mathrm{Sm}^{\mathrm{r}}$, and $\mathrm{Ap}^{\mathrm{r}}$ stand for resistance to kanamycin, spectinomycin, streptomycin, and ampicillin, respectively.

${ }^{\mathrm{b}} \mathrm{CIB}=$ Centro Nacional de Biotecnología, CSIC, Madrid. 
to confirm the loss of the delivery plasmid. The mutation grid was pooled as described by Holeva and associates (2004). ABF-0016056, $y b j X$, and $u n t M$ mutants were isolated from this grid. The mutants that were not found in this mutant bank (yeeZ and $a r n T$ ) were constructed by $\operatorname{Tn} 7$ in vitro mutagenesis using the Genome Priming System (GPS-1) kit (New England Biolabs, Beverly, MA, U.S.A.) and the marker-exchange was done as previously described by Roeder and Collmer (1985). In all cases, the mutations were verified by DNA sequencing analysis. Primers used for mutant identification or construction are described in Supplementary Table S1. Optical density at $600 \mathrm{~nm}\left(\mathrm{OD}_{600}\right)$ and $\mathrm{CFU}$ relationship and growth rates of the mutant strains did not show differences with those of the WT. Mutant complementation was performed using the high-copy plasmid pGEM-T easy expressing the corresponding WT gene.

\section{Microarray experiments.}

For these experiments, the 60-mer Erwinia chrysanthemi 11-K customer array (Agilent, Inc., Santa Clara, CA, U.S.A.) was used (Ravirala et al. 2007).

Starter cultures of $D$. dadantii 3937 and BT118 (phoP mutant) cells were grown to the late exponential phase $\left(\mathrm{OD}_{600}=1\right)$ in liquid N1 medium and then 20-fold diluted into $150 \mathrm{ml}$ of $0.3 \times \mathrm{N} 1$ medium (micromolar concentrations of $\mathrm{Mg}^{2+}$ and $\mathrm{Ca}^{2+}$ ) at $28^{\circ} \mathrm{C}$ on a rotary shaker at $250 \mathrm{rpm}$ to an $\mathrm{OD}_{600}$ of 0.2 . Then, each sample was divided into two halves. One half was exposed to a sub-lethal concentration of thionins $(30 \mu \mathrm{M})$ and the other half to distilled water as a control, and further incubated for 40 min. After the incubation, cells were harvested and total RNA from three biological replicates were isolated and purified with an RNeasy kit (Qiagen, Hilden, Germany). cDNA synthesis, labeling and hybridization were carried out as previously described by Antúnez-Lamas and associates (2009a).

Normalization and statistical analysis of the expression data were performed by using the LIMMA software package (Smyth 2004) as described by Antúnez-Lamas and associates (2009a). Linear model methods were used to determine genes differentially expressed. Each probe was tested for changes in expression over replicates using a moderated $t$ statistic (Smyth 2004). To control the false discovery rate (FDR), $P$ values were corrected by using the method of Benjamini and associates (2001). The expected FDR was controlled to be less than 5\%. A particular gene was considered differentially expressed if i) the foldchange was at least 1.95 and ii) the $P$ value was $<0.05$.

\section{qRT-PCR analysis.}

RNA (1 $\mu \mathrm{g})$ isolated as described above was used for cDNA synthesis using random hexamers with the High Capacity cDNA Reverse Transcription kit, according to the manufacturer's instructions (Applied Biosystems, Foster City, CA, U.S.A.). Specific primers were designed to amplify fragments of approximately $100 \mathrm{bp}$ for all genes (Supplementary Table $\mathrm{S} 2$ ). The $r p o S$ gene, which has been previously used as a control for qRT-PCR experiments in D. dadantii 3937 (Jahn et al. 2008), was chosen as an internal standard. qRT-PCR was performed in an ABI PRISM 7300 Real-Time PCR System (Applied Biosystems) using SYBR Green PCR master mix (Applied Biosystems) according to the manufacturer's instructions. Thermal conditions used were as follows: 1 cycle of $10 \mathrm{~min}$ at $95^{\circ} \mathrm{C}$; 50 cycles of $95^{\circ} \mathrm{C}$ for $15 \mathrm{~s}$ and $60^{\circ} \mathrm{C}$ for $1 \mathrm{~min}$; and 1 cycle of $15 \mathrm{~s}$ at $95^{\circ} \mathrm{C}, 30 \mathrm{~s}$ at $60^{\circ} \mathrm{C}$, and $15 \mathrm{~s}$ at $95^{\circ} \mathrm{C}$. The relative expression ratio was calculated as the differences between the cycle threshold $\left(\mathrm{C}_{\mathrm{t}}\right)$ values and was determined using the equation $2^{-\Delta \Delta \mathrm{Ct}}$ as previously modified (Pfaffl 2001; Rotenberg et al. 2006). A melting curve was performed at the end of each assay to certify the absence of primer-dimers and the presence of a single PCR product. Primer efficiencies were calculated as described by Pfaffl and associates (2004). Differences in relative expression ratio with respect to the internal control were analyzed by a one-tailed $t$ test using the Statgraphics software Plus 3.0 (StatPoint, Inc., St. Louis).

\section{Expression and purification of 6His-PhoP.}

The entire coding region of the $D$. dadantii 3937 phoP gene was cloned into pDEST17 expression vector (Invitrogen, Carlsbad, CA, U.S.A.). The 6His-PhoP fusion construct was transformed into Escherichia coli BL21 (DE3) cells (Novagen, Madison, WI, U.S.A.). Transformants were grown at $25^{\circ} \mathrm{C}$ to exponential phase and then 6 His-PhoP expression was induced by addition of $0.5 \mathrm{mM}$ isopropyl- $\beta$-D-thiogalactoside and further grown for $4 \mathrm{~h}$. 6His-PhoP protein was purified as described Yamamoto and associates (2002) with the following modifications: the column was washed with $5 \mathrm{ml}$ of ice-cold buffer $\mathrm{N}$ (20 mM Tris-HCl [pH 8.0], $0.1 \mathrm{mM}$ EDTA, $500 \mathrm{mM}$ $\mathrm{NaCl}, 5 \mathrm{mM}$ 2-mercaptoethanol, and 5\% [vol/vol] glycerol) containing $20 \mathrm{mM}$ imidazole and then with $5 \mathrm{ml}$ of buffer $\mathrm{N}$ containing $50 \mathrm{mM}$ imidazole. The $6 \mathrm{His}-\mathrm{PhoP}$ protein was then eluted in a three-step gradient with $2 \mathrm{ml}$ of ice-cold buffer $\mathrm{N}$ containing increasing amounts of imidazole (100, 150, and $250 \mathrm{mM}$ ). The purity of the $6 \mathrm{His}-\mathrm{PhoP}$ protein was checked by SDS polyacrylamide gel electrophoresis and Coomassie blue staining. Immunoblotting using an anti-His monoclonal antibody (GE Healthcare, Piscataway, NJ, U.S.A.) was performed to confirm the identity of the $6 \mathrm{His}-\mathrm{PhoP}$ protein.

\section{Electrophoretic mobility shift assay.}

DNA fragments of approximately $800 \mathrm{bp}$ upstream from the start codons containing the putative promoter regions of the ABF-0016056, untM, ybjX, arnT, yeeZ, and ABF-0020481 (used as a negative control) genes were amplified by PCR. Primers used are listed in Supplementary Table S3. PCR products were labeled with biotin using a universal biotinylated primer 5'-TTCAGACCAGACTCGTATCG-3'. DNA binding was performed in a reaction volume of $20 \mu \mathrm{l}$ containing binding buffer ( $1 \mathrm{mM} \mathrm{MgCl}_{2}, 0.5 \mathrm{mM}$ EDTA, $0.5 \mathrm{mM}$ DTT, 50 $\mathrm{mM} \mathrm{NaCl}, 10 \mathrm{mM}$ Tris-HCl [pH 7.5], and poly-dI-dC at 0.05 $\mathrm{mg} / \mathrm{ml})$, labeled DNA (100 fmol), and increasing amounts of the 6 His-PhoP protein. Two controls were included in each EMSA experiment: i) a cold probe with specific competitor DNA (unlabeled promoter region of each gene) and ii) a negative control with nonspecific DNA (unlabeled promoter region of ABF-0020481). The mix was incubated for $30 \mathrm{~min}$ at room temperature. Samples were loaded onto a native $4 \%$ (wt/vol) polyacrylamide gel and electrophoresed at $4{ }^{\circ} \mathrm{C}$ in $0.5 \times$ Trisborate-EDTA buffer for approximately $60 \mathrm{~min}$ at $100 \mathrm{~V}$. The DNA probes were transferred to a positively charged nylon membrane and detected according to the manufacturer's protocol of chemiluminescent nucleic acid detection module (Pierce, Rockford, IL, U.S.A.).

\section{Virulence assays.}

The pathogenicity of $D$. dadantii 3937 was evaluated in three host plants: potato tubers (Solanum tuberosum 'Monalisa'), heads of witloof chicory (Cichorium intybus), and leaves of African violet (Saintpaulia ionantha). All plant material was obtained from a local supermarket. Starter cultures of $D$. $d a$ dantii 3937 cells were grown to late exponential phase $\left(\mathrm{OD}_{600}\right.$ $1.0 ; 1 \mathrm{OD}_{600}$ corresponds to $\left.5 \times 10^{8} \mathrm{CFU} / \mathrm{ml}\right)$ in liquid $\mathrm{N} 1 \mathrm{me}-$ dium and then subcultured after 10 -fold dilution into $30 \mathrm{ml}$ of fresh medium at $28^{\circ} \mathrm{C}$ on a rotary shaker at $250 \mathrm{rpm}$ to an $\mathrm{OD}_{600}$ of 0.5 to 0.6 . Cultures were harvested by centrifugation $(4,000 \times g$ for $15 \mathrm{~min})$ at room temperature in a microfuge, then carefully washed with water twice and resuspended in a given volume to obtain the desired inoculum concentration. 
Virulence assays on witloof chicory leaves were carried out by measuring the macerated area after $24 \mathrm{~h}$ (Bauer et al. 1994). At least 20 leaves were pair inoculated with each mutant and the WT strain. The inoculum $(10 \mu \mathrm{l}$ of a bacterial suspension containing $5 \times 10^{4} \mathrm{CFU}$ ) was deposited on leaves previously wounded at the bottom with a pipette tip. The leaves were incubated in a moist chamber at $28^{\circ} \mathrm{C}$ for $24 \mathrm{~h}$. The macerated area was digitally measured using the software Image $\mathrm{J}$ and differences between the WT and the mutant strains were statistically assessed with a paired Student's $t$ test.

The $S$. ionantha plants were inoculated with $100 \mu \mathrm{l}$ of a bacterial suspension containing $5 \times 10^{6} \mathrm{CFU}$. Each strain was inoculated by syringe infiltration into the adaxial side of two leaves per plant (three biological replicates). Plants were incubated in a moist chamber at $28^{\circ} \mathrm{C}$ and symptoms were recorded after $48 \mathrm{~h}$.

Potato tubers were inoculated pairwise with the WT strain and with each of the mutant strains, with $50 \mu$ of a suspension containing $5 \times 10^{5} \mathrm{CFU}$ (López-Solanilla et al. 2001). A pipette tip containing the bacterial suspension was inserted at a constant depth of $1.5 \mathrm{~cm}$. Three inoculations (WT, mutant, and complemented strains) were made in each tuber. Potato tubers were left at $28^{\circ} \mathrm{C}$ in a moist chamber for $48 \mathrm{~h}$. After this time, tubers were sliced at the inoculation point, and the macerated tissue was carefully removed and weighted. Differences between the WT and the mutant were assessed statistically using a paired Student's $t$ test, and the same process was followed for WT and complemented strain comparison. Three different experiments were performed and at least 15 tubers per experiment were inoculated.

The virulence of $D$. dadantii 3937 and BT118 (phoP mutant) strains after a pretreatment with thionins was tested on potato tubers using the same procedure described above. Starter cultures of D. dadantii 3937 and BT118 cells were grown to the late exponential phase $\left(\mathrm{OD}_{600}=1.0\right)$ in $\mathrm{N} 1$ liquid medium and then subcultured after 20 -fold dilution into $150 \mathrm{ml}$ of $0.3 \times \mathrm{N} 1$ medium at $28^{\circ} \mathrm{C}$ on a rotary shaker at $250 \mathrm{rpm}$ to an $\mathrm{OD}_{600}$ of 0.2 . Then, each sample was divided into two halves. One of them was exposed to sub-lethal concentration of thionins (30 $\mu \mathrm{M})$ and the other one to distilled water as a control for $60 \mathrm{~min}$. After this time, the virulence assay was performed.

\section{Susceptibility assays.}

Thionins were purified from wheat flour as described by Ponz and associates (1982). Snakin-2 was purified from potato tubers as described by Lopez-Solanilla and associates (1998). Susceptibility to antimicrobial peptides was assayed as follows: exponentially growing cells in liquid N1 medium were diluted to $10^{5} \mathrm{CFU} / \mathrm{ml}$ in $0.3 \times$ liquid $\mathrm{N} 1$, and $10 \mu \mathrm{l}$ of the bacterial suspension was placed in an Eppendorf tube and the appropriate amount of peptide was added to reach the desired concentration. The mixture was incubated for $6 \mathrm{~h}$ at $28^{\circ} \mathrm{C}$ with shaking and then a portion of each sample was diluted and plated on N1 agar plates to assess bacterial viability.

\section{ACKNOWLEDGMENTS}

This research has been supported by the Spanish Plan Nacional I+D+I grant AGL-2009-12757. J. J. Rodríguez-Herva is funded by the program "Ramón y Cajal" from the Spanish Ministry of Science and Innovation (RYC-2007-01045). I. Rio-Alvarez is supported by the FPI program (MICINN-Spain). We acknowledge G. Garcia Casado (Centro Nacional de Biotecnología, CSIC, Madrid) for assistance with microarray data analysis.

\section{LITERATURE CITED}

Agrios, G. 2005. Plant Pathology. Elsevier Academic Press, New York. Alpuche-Aranda, C. M., Swanson, J. A., Loomis, W. P., and Miller, S. I.
1992. Salmonella typhimurium activates virulence gene transcription within acidified macrophage phagosomes. Proc. Natl. Acad. Sci. U.S.A. 89:10079-10083.

Antúnez-Lama, M., Cabrera, E., Lopez-Solanilla, E., Solano, R., GonzalezMelendi, P., Chico, J. M., Toth, I., Birch, P., Pritchard, L., Liu, H., and Rodriguez-Palenzuela, P. 2009a. Bacterial chemoattraction towards jasmonate plays a role in the entry of Dickeya dadantii through wounded tissues. Mol. Microbiol. 74:662-671.

Antúnez-Lama, M., Cabrera-Ordonez, E., Lopez-Solanilla, E., Raposo, R., Trelles-Salazar, O., Rodriguez-Moreno, A., and Rodriguez-Palenzuela, P. 2009b. Role of motility and chemotaxis in the pathogenesis of Dickeya dadantii 3937 (ex Erwinia chrysanthemi 3937). Microbiology 155:434-442.

Bader, M. W., Navarre, W. W., Shiau, W., Nikaido, H., Frye, J. G., McClelland, M., Fang, F. C., and Miller, S. I. 2003. Regulation of Salmonella typhimurium virulence gene expression by cationic antimicrobial peptides. Mol. Microbiol. 50:219-230.

Bader, M. W., Sanowar, S., Daley, M. E., Schneider, A. R., Cho, U., Xu, W., Klevit, R. E., Le Moual, H., and Miller, S. I. 2005. Recognition of antimicrobial peptides by a bacterial sensor kinase. Cell 122:461-472.

Bauer, D. W., Bogdanove, A. J., Beer, S. V., and Collmer, A. 1994 Erwinia chrysanthemi hrp genes and their involvement in soft rot pathogenesis and elicitation of the hypersensitive response. Mol. PlantMicrobe Interact. 7:573-581.

Belden, W. J., and Miller, S. I. 1994. Further characterization of the PhoP regulon: Identification of new PhoP-activated virulence loci. Infect. Immun. 62:5095-5101.

Benjamini, Y., Drai, D., Elmer, G., Kafkafi, N., and Golani, I. 2001. Controlling the false discovery rate in behavior genetics research. Behav. Brain Res. 125:279-284.)

Berrocal-Lobo, M., Segura, A., Moreno, M., Lopez, G., Garcia-Olmedo, F., and Molina, A. 2002. Snakin-2, an antimicrobial peptide from potato whose gene is locally induced by wounding and responds to pathogen infection. Plant Physiol. 128:951-961.

Boman, H. G. 1995. Peptide antibiotics and their role in innate immunity. Annu. Rev. Immunol. 13:61-92.

Brodsky, I. E., Ghori, N., Falkow, S., and Monack, D. 2005. Mig-14 is an inner membrane-associated protein that promotes Salmonella typhimurium resistance to CRAMP, survival within activated macrophages and persistent infection. Mol. Microbiol. 55:954-972.

Brogden, K. A. 2005. Antimicrobial peptides: Pore formers or metabolic inhibitors in bacteria? Nat. Rev. Microbiol. 3:238-250.

Caaveiro, J. M., Molina, A., Gonzalez-Manas, J. M., RodriguezPalenzuela, P., Garcia-Olmedo, F., and Goni, F. M. 1997. Differential effects of five types of antipathogenic plant peptides on model membranes. FEBS (Fed. Eur. Biochem. Soc.) Lett. 410:338-342.

Costechareyre, D., Dridi, B., Rahbe, Y., and Condemine, G. 2010. Cyt toxin expression reveals an inverse regulation of insect and plant virulence factors of Dickeya dadantii. Environ. Microbiol. 12:3290-3301.

Detweiler, C. S., Monack, D. M., Brodsky, I. E., Mathew, H., and Falkow, S. 2003. virK, somA and $r c s C$ are important for systemic Salmonella enterica serovar typhimurium infection and cationic peptide resistance. Mol. Microbiol. 48:385-400.

Eguchi, Y., Okada, T., Minagawa, S., Oshima, T., Mori, H., Yamamoto, K., Ishihama, A., and Utsumi, R. 2004. Signal transduction cascade between EvgA/EvgS and PhoP/PhoQ two-component systems of Escherichia coli. J. Bacteriol. 186:3006-3014.

Enard, C., and Expert, D. 2000. Characterization of a tonB mutation in Erwinia chrysanthemi 3937: TonB(Ech) is a member of the enterobacterial TonB family. Microbiology $146: 2051-2058$.

Fagard, M., Dellagi, A., Roux, C., Périno, C., Rigault, M., Boucher, V., Shevchik, V. E., and Expert, D. 2007. Arabidopsis thaliana expresses multiple lines of defense to counterattack Erwinia chrysanthemi. Mol. Plant-Microbe Interact. 20:794-805.

Franza, T., Mahe, B., and Expert, D. 2005. Erwinia chrysanthemi requires a second iron transport route dependent of the siderophore achromobactin for extracellular growth and plant infection. Mol. Microbiol. 55:261275.

Garcia-Olmedo, F., Molina, A., Alamillo, J. M., and RodriguezPalenzuela, P. 1998. Plant defense peptides. Biopolymers 47:479-491.

Garcia Vescovi, E., Soncini, F. C., and Groisman, E. A. $1996 . \mathrm{Mg}^{2+}$ as an extracellular signal: Environmental regulation of Salmonella virulence. Cell 84:165-174.

Gooderham, W. J., Bains, M., McPhee, J. B., Wiegand, I., and Hancock, R. E. 2008. Induction by cationic antimicrobial peptides and involvement in intrinsic polymyxin and antimicrobial peptide resistance, biofilm formation, and swarming motility of PsrA in Pseudomonas aeruginosa. J. Bacteriol. 190:5624-5634.

Groisman, E. A. 2001. The pleiotropic two-component regulatory system PhoP-PhoQ. J. Bacteriol. 183:1835-1842. 
Groisman, E. A., Chiao, E., Lipps, C. J., and Heffron, F. 1989. Salmonella typhimurium phoP virulence gene is a transcriptional regulator. Proc. Natl. Acad. Sci. U.S.A. 86:7077-7081.

Gunn, J. S. 2008. The Salmonella PmrAB regulon: Lipopolysaccharide modifications, antimicrobial peptide resistance and more. Trends $\mathrm{Mi}$ crobiol. 16:284-290.

Gunn, J. S., Lim, K. B., Krueger, J., Kim, K., Guo, L., Hackett, M., and Miller, S. I. 1998. PmrA-PmrB-regulated genes necessary for 4-aminoarabinose lipid A modification and polymyxin resistance. Mol. Microbiol. 27:1171-1182.

Guo, L., Lim, K. B., Poduje, C. M., Daniel, M., Gunn, J. S., Hackett, M., and Miller, S. I. 1998. Lipid A acylation and bacterial resistance against vertebrate antimicrobial peptides. Cell 95:189-198.

Hammami, R., Ben Hamida, J., Vergoten, G., and Fliss, I. 2009. PhytAMP: A database dedicated to antimicrobial plant peptides. Nucleic Acids Res. 37:D963-D968.

Hanahan, D. 1983. Studies on transformation of Escherichia coli with plasmids. J. Mol. Biol. 166:557-580.

Haque, M. M., and S. Tsuyumu 2005. Virulence, resistance to magainin II and expression of pectate lyase are controlled by the PhoP-PhoQ two com- ponent regulatory system responding to $\mathrm{pH}$ and magnesium in Erwinia chrysanthemi 3937. J. Gen. Plant Pathol. 71:47-53.

Herrera, C. M., Hankins, J. V., and Trent, M. S. 2010. Activation of PmrA inhibits LpxT-dependent phosphorylation of lipid A promoting resistance to antimicrobial peptides. Mol. Microbiol. 76:1444-1460.

Hoffman, J. A. 1995. Innate immunity of insects. Curr. Opin. Immunol. 7:4-10.

Holeva, M. C., Bell, K. S., Hyman, L. J., Avrova, A. O., Whisson, S. C., Birch, P. R., and Toth, I. K. 2004. Use of a pooled transposon mutation grid to demonstrate roles in disease development for Erwinia carotovora subsp. atroseptica putative type III secreted effector (DspE/A) and helper $(\mathrm{HrpN})$ proteins. Mol. Plant-Microbe Interact. 17:943-950.

Hommais, F., Oger-Desfeux, C., Van Gijsegem, F., Castang, S., Ligori, S., Expert, D., Nasser, W., and Reverchon, S. 2008. PecS is a global regulator of the symptomatic phase in the phytopathogenic bacterium Erwinia chrysanthemi 3937. J. Bacteriol. 190:7508-7522.

Jahn, C. E., Charkowski, A. O., and Willis, D. K. 2008. Evaluation of isolation methods and RNA integrity for bacterial RNA quantitation. J. Microbiol. Methods 75:318-324.

Kato, A., Tanabe, H., and Utsumi, R. 1999. Molecular characterization of the PhoP-PhoQ two-component system in Escherichia coli K-12: Identification of extracellular $\mathrm{Mg}^{2+}$-responsive promoters. J. Bacteriol. 181:5516-5520

King, E. O., Ward, M. K., and Raney, D. E. 1954. Two simple media for the demonstration of pyocyanin and fluorescin. J. Lab. Clin. Med. 44:301-307.

Kocks, C., Marchand, J. B., Gouin, E., d'Hauteville, H., Sansonetti, P. J., Carlier, M. F., and Cossart, P. 1995. The unrelated surface proteins ActA of Listeria monocytogenes and IcsA of Shigella flexneri are sufficient to confer actin-based motility on Listeria innocua and Escherichia coli respectively. Mol. Microbiol. 18:413-423.

Kotoujansky, A., Diolez, A., Boccara, M., Bertheau, Y., Andro, T., and Coleno, A. 1985. Molecular cloning of Erwinia chrysanthemi pectinase and cellulase structural genes. EMBO (Eur. Mol. Biol. Organ.) J. 4:781785

Lejona, S., Aguirre, A., Cabeza, M. L., Garcia Vescovi, E., and Soncini, F. C. 2003. Molecular characterization of the $\mathrm{Mg}^{2+}$-responsive PhoPPhoQ regulon in Salmonella enterica. J. Bacteriol. 185:6287-6294.

Li, Y., Peng, Q., Selimi, D., Wang, Q., Charkowski, A. O., Chen, X., and Yang, C. H. 2009. The plant phenolic compound p-coumaric acid represses gene expression in the Dickeya dadantii type III secretion system. Appl. Environ. Microbiol. 75:1223-1228.

Llama-Palacios, A., Lopez-Solanilla, E., Poza-Carrion, C., GarciaOlmedo, F., and Rodriguez-Palenzuela, P. 2003. The Erwinia chrysanthemi phoP-phoQ operon plays an important role in growth at low $\mathrm{pH}$, virulence and bacterial survival in plant tissue. Mol. Microbiol. 49:347-357

Llama-Palacios, A., Lopez-Solanilla, E., and Rodriguez-Palenzuela, P. 2005. Role of the PhoP-PhoQ system in the virulence of Erwinia chrysanthemi strain 3937: Involvement in sensitivity to plant antimicrobial peptides, survival at acid $\mathrm{Hh}$, and regulation of pectolytic enzymes. J. Bacteriol. 187:2157-2162.

Lopez-Solanilla, E., Garcia-Olmedo, F., and Rodriguez-Palenzuela, P. 1998. Inactivation of the sapA to sapF locus of Erwinia chrysanthemi reveals common features in plant and animal bacterial pathogenesis. Plant Cell 10:917-924.

Lopez-Solanilla, E., Llama-Palacios, A., Collmer, A., Garcia-Olmedo, F. and Rodriguez-Palenzuela, P. 2001. Relative effects on virulence of mutations in the sap, pel, and hrp loci of Erwinia chrysanthemi. Mol. Plant-Microbe Interact. 14:386-393.
Maggiorani Valecillos, A., Rodriguez Palenzuela, P., and Lopez-Solanilla, E. 2006. The role of several multidrug resistance systems in Erwinia chrysanthemi pathogenesis. Mol. Plant-Microbe Interact. 19:607-613.

Mahé, B., Masclaux, C., Rauscher, L., Enard, C., and Expert, D. 1995. Differential expression of two siderophore-dependent iron-acquisition pathways in Erwinia chrysanthemi 3937: Characterization of a novel ferrisiderophore permease of the ABC transporter family. Mol. Microbiol. 18:33-43.

Miller, S. I., Kukral, A. M., and Mekalanos, J. J. 1989. A two-component regulatory system (phoP phoQ) controls Salmonella typhimurium virulence. Proc. Natl. Acad. Sci. U.S.A. 86:5054-5058.

Münzinger, M., Budzikiewicz, H., Expert, D., Enard, C., and Meyer, J. M. 2000. Achromobactin, a new citrate siderophore of Erwinia chrysanthemi. Z Naturforsch C 55:328-332.

Nakata, N., Sasakawa, C., Okada, N., Tobe, T., Fukuda, I., Suzuki, T., Komatsu, K., and Yoshikawa, M. 1992. Identification and characterization of virK, a virulence-associated large plasmid gene essential for intercellular spreading of Shigella flexneri. Mol. Microbiol. 6:2387-2395.

Nasser, W., and Reverchon, S. 2002. H-NS-dependent activation of pectate lyases synthesis in the phytopathogenic bacterium Erwinia chrysanthemi is mediated by the PecT repressor. Mol. Microbiol. 43:733-748.

Novik, V., Hofreuter, D., and Galan, J. E. 2009. Characterization of a Campylobacter jejuni VirK protein homolog as a novel virulence determinant. Infect. Immun. 77:5428-5436.

Otto, M. 2009. Bacterial sensing of antimicrobial peptides. Contrib. Microbiol. 16:136-149.

Parra-Lopez, C., Baer, M. T., and Groisman, E. A. 1993. Molecular genetic analysis of a locus required for resistance to antimicrobial peptides in Salmonella typhimurium. EMBO (Eur. Mol. Biol. Organ.) J. 12:4053-4062.

Perera, I. C., and Grove, A. 2010. Urate is a ligand for the transcriptional regulator PecS. J. Mol. Biol. 402:539-551.

Perez, J. C., Shin, D., Zwir, I., Latifi, T., Hadley, T. J., and Groisman, E. A. 2009. Evolution of a bacterial regulon controlling virulence and $\mathrm{Mg}^{2+}$ homeostasis. PLoS Genet. 5:e1000428. Published online.

Persmark, M. D., Expert, D., and Neilands, J. B. 1989. Isolation, characterization, and synthesis of chrysobactin, a compound with siderophore activity from Erwinia chrysanthemi. J. Biol. Chem. 264:3187-3193.

Peschel, A. 2002. How do bacteria resist human antimicrobial peptides? Trends Microbiol. 10:179-186.

Pfaffl, M. W. 2001. A new mathematical model for relative quantification in real-time RT-PCR. Nucleic Acids Res. 29:e45.

Pfaffl, M. W., Tichopad, A., Prgomet, C., and Neuvians, T. P. 2004. Determination of stable housekeeping genes, differentially regulated target genes and sample integrity: BestKeeper-Excel-based tool using pairwise correlations. Biotechnol. Lett. 26:509-515.

Pietiainen, M., Francois, P., Hyyrylainen, H. L., Tangomo, M., Sass, V., Sahl, H. G., Schrenzel, J., and Kontinen, V. P. 2009. Transcriptome analysis of the responses of Staphylococcus aureus to antimicrobial peptides and characterization of the roles of $v \mathrm{raDE}$ and $v \mathrm{raSR}$ in antimicrobial resistance. BMC Genomics 10:429.

Ponz, F., Hernandez-Lucas, C., Carbonero, P., and Garcia-Olmedo, F. 1982. Lipid-binding proteins from the endosperms of wheat and oats. Phytochemistry 23:2178-2181

Ravirala, R. S., Barabote, R. D., Wheeler, D. M., Reverchon, S., Tatum, O., Malouf, J., Liu, H., Pritchard, L., Hedley, P. E., Birch, P. R., Toth, I. K., Payton, P., and San Francisco, M. J. 2007. Efflux pump gene expression in Erwinia chrysanthemi is induced by exposure to phenolic acids. Mol. Plant-Microbe Interact. 20:313-320.

Roeder, D. L., and Collmer, A. 1985. Marker-exchange mutagenesis of a pectate lyase isozyme gene in Erwinia chrysanthemi. J. Bacteriol. 164:5156.

Rotenberg, D., Thompson, T. S., German, T. L., and Willis, D. K. 2006 Methods for effective real-time RT-PCR analysis of virus-induced gene silencing. J. Virol. Methods 138:49-59.

Sambrook, J., Frits, E. F., and Maniatis, T. 1989. Molecular Cloning: A Laboratory Manual, 2nd ed. Cold Spring Harbor Laboratory Press, Cold Spring Harbor, NY, U.S.A.

Shere, K. D., Sallustio, S., Manessis, A., D’Aversa, T. G., and Goldberg, M. B. 1997. Disruption of IcsP, the major Shigella protease that cleaves IcsA, accelerates actin-based motility. Mol. Microbiol. 25:451-462.

Smith, R. L., Kaczmarek, M. T., Kucharski, L. M., and Maguire, M. E. 1998. Magnesium transport in Salmonella typhimurium: Regulation of mgtA and mgtCB during invasion of epithelial and macrophage cells. Microbiology 144:1835-1843.

Smyth, G. K. 2004. Linear models and empirical Bayes methods for assessing differential expression in microarray experiments. Stat. Appl Genet. Mol. Biol. 3:Article3.

Soncini, F. C., Garcia Vescovi, E., Solomon, F., and Groisman, E. A. 1996. Molecular basis of the magnesium deprivation response in Salmonella 
typhimurium: Identification of PhoP-regulated genes. J. Bacteriol 178:5092-5099.

Titarenko, E., Lopez-Solanilla, E., Garcia-Olmedo, F., and RodriguezPalenzuela, P. 1997. Mutants of Ralstonia (Pseudomonas) solanacearum sensitive to antimicrobial peptides are altered in their lipopolysaccharide structure and are avirulent in tobacco. J. Bacteriol. 179:6699-6704.

Toth, I. K., Bell, K. S., Holeva, M. C., and Birch, P. R. 2003. Soft rot erwiniae: From genes to genomes. Mol. Plant Pathol. 4:17-30.

Touze, T., Blanot, D., and Mengin-Lecreulx, D. 2008. Substrate specificity and membrane topology of Escherichia coli PgpB, an undecaprenyl pyrophosphate phosphatase. J. Biol. Chem. 283:16573-16583.

Trent, M. S., Ribeiro, A. A., Lin, S., Cotter, R. J., and Raetz, C. R. 2001 An inner membrane enzyme in Salmonella and Escherichia coli that transfers 4-amino-4-deoxy-L-arabinose to lipid A: Induction on polymyxin-resistant mutants and role of a novel lipid-linked donor. J. Biol. Chem. 276:43122-43131.

Venkatesh, B., Babujee, L., Liu, H., Hedley, P., Fujikawa, T., Birch, P., Toth, I., and Tsuyumu, S. 2006. The Erwinia chrysanthemi 3937 PhoQ sensor kinase regulates several virulence determinants. J. Bacteriol. 188:3088-3098.

Wilson, K. J., Sessitsch, A., Corbo, J. C., Giller, K. E., Akkermans, A. D., and Jefferson, R. A. 1995. $\beta$-Glucuronidase (GUS) transposons for ecological and genetic studies of rhizobia and other gram-negative bacteria. Microbiology 141:1691-1705.

Winfield, M. D., and Groisman, E. A. 2004. Phenotypic differences between Salmonella and Escherichia coli resulting from the disparate regu- lation of homologous genes. Proc. Natl. Acad. Sci. U.S.A. 101:17162 17167.

Wing, H. J., Goldman, S. R., Ally, S., and Goldberg, M. B. 2005. Modulation of an outer membrane protease contributes to the virulence defect of Shigella flexneri strains carrying a mutation in the virK locus. Infect. Immun. 73:1217-1220.

Yamamoto, K., Ogasawara, H., Fujita, N., Utsumi, R., and Ishihama, A. 2002. Novel mode of transcription regulation of divergently overlapping promoters by PhoP, the regulator of two-component system sensing external magnesium availability. Mol. Microbiol. 45:423-438.

Yang, S., Perna, N. T., Cooksey, D. A., Okinaka, Y., Lindow, S. E., Ibekwe, A. M., Keen, N. T., and Yang, C. H. 2004. Genome-wide identification of plant-upregulated genes of Erwinia chrysanthemi 3937 using a GFP-based IVET leaf array. Mol. Plant-Microbe Interact. 17:999-1008.

Yang, S., Peng, Q., San Francisco, M., Wang, Y., Zeng, Q., and Yang, C. H. 2008. Type III secretion system genes of Dickeya dadantii 3937 are induced by plant phenolic acids. PLoS One 3:e2973. Published online.

Yang, S., Peng, Q., Zhang, Q., Zou, L., Li, Y., Robert, C., Pritchard, L., Liu, H., Hovey, R., Wang, Q., Birch, P., Toth, I. K., and Yang, C. H. 2010. Genome-wide identification of HrpL-regulated genes in the necrotrophic phytopathogen Dickeya dadantii 3937. PLoS One 5:e13472. Published online.

Yap, M. N., Yang, C. H., and Charkowski, A. O. 2008. The Response regulator HrpY of Dickeya dadantii 3937 regulates virulence genes not linked to the hrp cluster. Mol. Plant-Microbe Interact. 21:304-314. 